\section{For dem som har diabetes - og også for dem som hjelper dem}

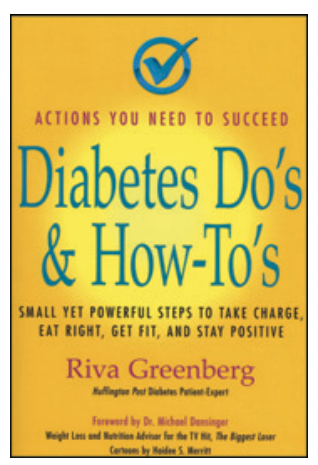

Riva Greenburg

Diabetes do's \& how-to's

Small yet powerful steps to take charge, eat right, get fit, and stay positive. $273 \mathrm{~s}$, ill. Brooklyn, NY: SPI Management LLC, 2013. Pris USD 17

ISBN 978-0-9822906-1-3

«Diabetes education has become not an element of the treatment, but the treatment itself», skrev Joslin for mange år siden. I dag er det vanlig å fremheve at den som har diabetes, er det viktigste medlemmet i behandlingsteamet. Behandlingen foregår hele tiden, og det er også den som har diabetes, som må unngjelde hvis behandlingen er dårlig. Det er gjennom tidene skrevet tallrike artikler og bøker som skal hjelpe den som har diabetes til å behandle sin sykdom best mulig. Denne er fra USA og skrevet litt etter den modellen som kalles For Dummies. Faglig kvalitet er likevel høy, og boken er klok, informativ og samtidig lettlest. Den er rikelig og morsomt illustrert.

Jeg har lyst til å sitere: «I once went on a long weekend with two female friends who also have type 1 diabetes. We each ate exactly the same meals and did the same exercise, and we each got different numbers checking our blood sugar throughout the day. There is no value in comparing yourself to others, honestly, it bummed you in high school and will only confuse you now.» For å si det på norsk, alle med diabetes må selv finne ut hva som passer for seg og sin diabetes.

Er det noe jeg savner? Egentlig ikke. Hun skriver godt om svangerskap, om hvordan man skal bruke helsetjenesten, om hvilke prøver som bør tas regelmessig, inklusive mikroalbumin og andre risikofaktorer for hjertesykdom. Det blir også sagt klart fra at det ikke er lurt å røyke. Denne boken passer nok best for mennesker med type 1-diabetes, men vil også være nyttig for dem med type 2. For oss i Norge tror jeg at vi som hjelper folk med diabetes, kanskje vil ha størst glede av å lese boken og ha den tilgjengelig når vi forbereder undervisning.

I Norge har vi i dag en brukerversjon av de kliniske retningslinjene for diabetes, utgitt i samarbeid mellom Helsedirektoratet og Diabetesforbundet. Den har en helt annen form, men gir de samme rådene. Personlig ville jeg foretrekke den, men jeg tror at mange pasienter med gode engelskkunnskaper ville ha større nytte og glede av Diabetes Do's \& How-To's.

\section{Jak Jervell}

Professor emeritus

Oslo

\section{Ti personlige fortellinger om internasjonalt helsearbeid}

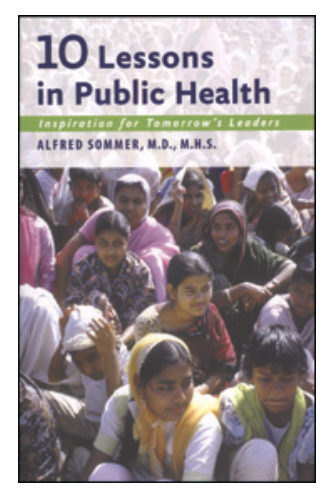

Alfred Sommer

Ten lessons in public health

Inspiration for tomorrow's leaders. 83 s, ill.

Baltimore, MD: The John Hopkins University

Press, 2013. Pris USD 20

ISBN 978-1-4214-0904-7

Denne boken viste seg å være noe annet enn det jeg antok ut fra tittelen og forlagsomtalen. Det er ikke noen kortfattet innføring i sentrale temaer innen offentlig helsearbeid - til inspirasjon for unge samfunnsmedisinere som vil opp og frem. Jeg kan heller ikke se at den forklarer hvordan den moderne epoken for forskning innen samfunnsmedisin ble født, slik man hevder i forlagets informasjonsark.

Forfatteren har siden slutten av 1960-årene vært engasjert i internasjonalt helsearbeid. Det startet med at han som legekandidat søkte seg til Epidemic Intelligence Service (EIS) under Centers for Disease Control (CDS) for å slippe tjeneste i Vietnam. Han kom til daværende Øst-Pakistan for å arbeide med kolera. Der ble han kastet inn i hjelpearbeidet etter syklonen, som i oktober 1970 tok en kvart million menneskeliv i løpet av en natt. Året etter måtte han evakueres i forbindelse med revolusjonen som førte til opprettelsen av staten Bangladesh.

Så gikk ferden videre til Afrika, Iran, Indonesia, Latin-Amerika og Karibien. Mest interessant for anmelderen er beretningen om kampen mot blindhet på grunn av mangel på A-vitamin, både gjennom kurative og profylaktiske tiltak.

De ti kapitlene er lettleste, sterkt personlig vinklet, til dels med anekdotiske islett. Han ønsker å få frem tre hovedpoenger. Det første er at man kan hjelpe sine medmennesker ved å reise dit man trengs. Det andre poenget er at fakta- og databasert forskning er nødvendig for å bedre folkehelsen. Det tredje og siste poenget er at man må lære seg å håndtere kollisjoner mellom fag, kultur og sosiologiske forhold.

Han hever seg imidlertid sjelden opp på et analytisk systemnivå, hvor de store linjene i de globale helseutfordringene synes.

Jeg er usikker på hvem som kan være i målgruppen her i landet. Kanskje kan den være til inspirasjon for idealistiske yngre kolleger som ønsker å gjøre en innsats der det trengs mest i den tredje verden? Kanskje kan veteraner innen internasjonal helse ha glede av å nikke gjenkjennende til Sommers opplevelser og observasjoner?

\section{Kristian Hagestad}

Helse- og omsorgsavdelingen

Fylkesmannen i Vest-Agder 